\title{
Effects of Standardization of Whole Milk with Dry Milk Protein Concentrate on the Yield and Ripening of Reduced-Fat Cheddar Cheese
}

\author{
Shakeel-Ur-Rehman, ${ }^{*}$ N. Y. Farkye, ${ }^{*}$ T. Considine, ${ }^{*}$ A. Schaffner, $†$ and M. A. Drake‡ \\ *Dairy Products Technology Center, \\ †Statistics Department, California Polytechnic State University, San Luis Obispo 93407; \\ ¥Southeast Dairy Research Center, Department of Food Science, North Carolina State University, Raleigh 27695
}

\begin{abstract}
Commercial milk protein concentrate (MPC) was used to standardize whole milk for reduced-fat Cheddar cheesemaking. Four replicate cheesemaking trials of three treatments (control, MPC1, and MPC2) were conducted. The control cheese (CC) was made from standardized milk (casein-to-fat ratio, $\mathrm{C} / \mathrm{F} \sim 1.7$ ) obtained by mixing skim milk and whole milk (WM); MPC1 and MPC2 cheeses were made from standardized milk (C/ $\mathrm{F}$ 1.8) obtained from mixing WM and MPC, except that commercial mesophilic starter was added at the rate of $1 \%$ to the $\mathrm{CC}$ and MPC1 and $2 \%$ to MPC2 vats. The addition of MPC doubled cheese yields and had insignificant effects on fat recoveries ( $94 \%$ in MPC1 and MPC2 vs. $\sim 92 \%$ in CC) but increased significantly total solids recoveries ( $63 \%$ in CC vs. $63 \%$ in MPC1 and MPC2). Although minor differences were noted in the gross composition of the cheeses, both MPC1 and MPC2 cheeses had lower lactose contents $(0.25$ or $0.32 \%$, respectively) than in $\mathrm{CC}(0.60 \%) 7 \mathrm{~d}$ post manufacture. Cheeses from all three treatments had $\sim 10^{9}$ $\mathrm{cfu} / \mathrm{g}$ initial starter bacteria count. The nonstarter lactic acid bacteria (NSLAB) grew slowly in MPC1 and MPC2 cheeses during ripening compared to $\mathrm{CC}$, and at the end of 6 mo of ripening, numbers of NSLAB in the CC were 1 to 2 log cycles higher than in MPC1 and MPC2 cheeses. Primary proteolysis, as noted by water-soluble $\mathrm{N}$ contents, was markedly slower in MPC1 and MPC2 cheeses compared to CC. The concentrations of total free amino acids were in decreasing order CC > MPC2 $>$ MPC1 cheeses, suggesting slower secondary proteolysis in the MPC cheeses than in CC. Sensory analysis showed that MPC cheeses had lower brothy and bitter scores than CC. Increasing the amount of starter bacteria improved maturity in MPC cheese.
\end{abstract}

(Key words: Milk protein concentrate powder, proteolysis, reduced-fat Cheddar)

Received: September 25, 2002.

Accepted: December 10, 2002.

Corresponding author: N. Y. Farkye; e-mail:nfarkye@calpoly.edu.
Abbreviation key: $\mathbf{C C}=$ control cheese, $\mathbf{F D M}=$ fat in DM, MPC = milk protein concentrate, $\mathbf{N S L A B ~ = ~}$ nonstarter lactic acid bacteria, $\mathbf{R F C}=$ reduced-fat cheddar, $\mathbf{S M}=$ skim milk, $\mathbf{S M P}=$ skim milk powder, $\mathbf{W M}=$ whole milk, $\mathbf{W S F}=$ water-soluble fraction.

\section{INTRODUCTION}

Lower-fat cheeses (i.e., low-fat and reduced-fat) are manufactured either by technological manipulation of the manufacturing protocols or by use of special starter cultures and adjuncts, or by use of additives and fat substitutes in order to achieve attributes similar to corresponding full-fat varieties. Technologies for the manufacture of lower-fat cheese involve some form of standardization of milk, which is achieved by removal of a portion of milk fat as cream or addition of casein in the form of skim milk powder (SMP) or condensed skim. Other technologies for the manufacture of lower-fat cheese involve use of membrane filtration of milk (Pierre et al., 1992; St-Gelais et al., 1995). Although sensory attributes of the resultant cheese are important for consumer acceptability, economic consideration such as product yield are equally important to the manufacturer and, ultimately, the consumer. The removal of milk fat generally results in decreased yields and, conversely, standardization by the addition of casein is more attractive due to increased yields.

Each method of standardization presents some disadvantages, e.g., addition of SMP or condensed skim increases the amount of lactose in cheese milk and consequently, the level of residual lactose in the cheese increases, thereby increasing the chances of undesirable fermentation during ripening. Anderson et al. (1993) reported that addition of condensed skim leads to atypical flavor in cheese and high levels of lactose may result in white crystal defect (Dybing et al., 1986). There is little or no published information on the use of milk protein concentrate (MPC) for standardization on the resultant reduced-fat cheese yield and quality.

MPC, which is produced by spray drying of skim milk retentate, contains approximately $65 \%$ protein, $3 \%$ fat, 
$2.0 \% \mathrm{Ca}$, and $20 \%$ lactose, compared with SMP, which contains about $0.7 \%$ fat, $36.0 \%$ protein, and $51 \%$ lactose or condensed skim, which contains about $0.5,9.3$, and $14 \%$ fat, protein, and lactose, respectively. The use of MPC for standardization of whole milk for cheese manufacture offers several advantages including high yield, high quality of the whey stream due to reduced lactose levels in MPC and, consequently, reduced residual lactose level in cheese compared to using condensed skim or SMP. Thus, the aim of this study was to determine the effects of standardization of whole milk with MPC for reduced-fat Cheddar cheese manufacture and to determine the effects of starter activity on the quality of reduced-fat cheese made with MPC-fortified milk.

\section{MATERIALS AND METHODS}

\section{Cheese Manufacture}

Three vats (A, B, and C) of reduced-fat Cheddar cheese (RFC) were manufactured on four occasions (four trials). Vat A control cheese; (CC) contained standardized milk consisting of skim milk (SM) plus whole milk (WM). Standardized milk for vats B (MPC1) and C (MPC2) contained WM and MPC. Target casein/fat ratio in the standardized milk was 1.8. MPC was obtained from Main Street Ingredients, La Crosse, Wisconsin. It contained $63.5 \%$ protein, $20.9 \%$ lactose, $5 \%$ moisture, $3.1 \%$ fat, and $7.5 \%$ ash. MPC and raw WM were mixed in a tank before pasteurization. For vat A, $\mathrm{WM}$ and SM were mixed in the ratio of 36 and 64 parts, respectively, whereas for vats $\mathrm{B}$ and $\mathrm{C}, \mathrm{WM}$ and $\mathrm{MPC}$ were mixed in the ratio of 91.6 and 8.3 parts, respectively. Each standardized milk $(\sim 125 \mathrm{~kg})$ was pasteurized at $72^{\circ} \mathrm{C} \times 16 \mathrm{~s}$ using a universal pilot plant pasteurizer (PMS Processing Machine and Supply Co., Philadelphia, PA) having capacity to process $1.9 \mathrm{~L}$ of milk per min and cooled to $31^{\circ} \mathrm{C}$. The beginning and end of each standardized milk $(\sim 10 \mathrm{~kg})$ existing the HTST was discarded, and $100 \mathrm{~kg}$ was poured in the vat for cheese making. Frozen starter (Lacococcus lactis ssp. lactis SCO352) obtained from Chr Hansen Inc., Milwaukee, WI, was propagated in $10 \%$ (wt/wt) sterile SM reconstituted from low-heat skim milk powder and was added to each vat at the rate of $1 \%$, wt/wt for vats $\mathrm{A}$ and $\mathrm{B}$ and at $2 \%, \mathrm{wt} / \mathrm{wt}$ for vat $\mathrm{C}$. The vat contents were held for $30 \mathrm{~min}$ to ripen. Then, rennet (Chymax, Chr Hansen, was added ( $45 \mathrm{~mL} / 454 \mathrm{~kg}$ milk) to each vat, followed by a 2 -min stirring and the milk held undisturbed until a firm coagulum formed ( $\sim 30 \mathrm{~min})$. The coagulum was cut with 1-cm horizontal and vertical curd wire knives. The cut curds were healed for 2 to 3 min before slow stirring for $10 \mathrm{~min}$. The curd was cooked to $38^{\circ} \mathrm{C}$ over 30 min, with gentle stirring until the curd $\mathrm{pH}$ (measured by inserting $\mathrm{pH}$ electrode directly into a sample of squeezed curd) reached 6.2 in 30 to $40 \mathrm{~min}$. The whey was drained, followed by matting and cheddaring of curds until the curd $\mathrm{pH}$ reached 5.6. The matted curds were milled and salted at the rate of $2.2 \%$ (wt/wt) of curd weight. It took $\sim 4$ to $5 \mathrm{~h}$ from setting to milling. The salted curds were hooped and pressed $(310 \mathrm{kPa})$ for $12 \mathrm{~h}$. The pressed cheeses were then vacuum packaged in Cryovac bags and ripened at $8^{\circ} \mathrm{C}$.

\section{Yield}

The yield of cheese was determined by weighing the cheese obtained in each vat after removal from the press, and it was expressed as a percentage of the milk weight.

\section{Compositional Analyses}

The fat content in milk and cheese was analyzed by the Babcock method (Marshall, 1992). Casein in milk was determined by the formol titration (Price, 1953). Total solids in whey and milk were determined by the microwave oven method (CEM AVC 80 microwave oven, CEM Corp., Mattehew, NC; Marshall, 1992). Protein (total $\mathrm{N} \times 6.38$ ) was determined by the Kjeldahl method, salt by titration using the Corning 926 Chloride analyzer (Corning, Medfield, MA), and lactose by enzymatic method (Boehringer Mannheim Biochemicals, Mannheim, Germany). Cheese $\mathrm{pH}$ was determined using a glass electrode on a slurry prepared by thoroughly blending $10 \mathrm{~g}$ of grated cheese with $10 \mathrm{ml}$ of deionized water using a mortar and pestle. Cheeses were analyzed 7-d post manufacture. All analyses were done in duplicate.

\section{Microbiological Analysis}

Starter bacteria were enumerated only on 1-d-old cheeses on LM-17 agar (Difco Laboratories, Detroit, MI) after incubation for $3 \mathrm{~d}$ at $31^{\circ} \mathrm{C}$. Starter were enumerated on 1-d-old cheeses because nonstarter lactic acid bacteria (NSLAB) grow on LM17 agar in later stages of ripening and make the interpretation of the counts difficult (Cogan and Beresford, 2002). NSLAB in the cheeses were enumerated on Rogosa agar (Difco Laboratories) after incubation for $5 \mathrm{~d}$ at $31^{\circ} \mathrm{C}$. Cheeses $(10$ g) were blended with warm $2 \%$ sodium citrate followed by dilution in $0.1 \%$ peptone water before pour-plating on agar.

\section{Proteolysis}

Samples of cheese were taken after 7, 30, 90, 180, and $300 \mathrm{~d}$ of ripening and frozen at $-20^{\circ} \mathrm{C}$ until analyzed 
Table 1. Mean* ( \pm SEM) concentrations of fat, casein, and total solids in milk, and fat and total solids in whey during reduced-fat Cheddar cheese manufacture. ${ }^{1}$

\begin{tabular}{|c|c|c|c|c|c|c|}
\hline \multirow[b]{2}{*}{ Vat } & \multicolumn{3}{|c|}{ Milk } & \multicolumn{3}{|c|}{ Whey } \\
\hline & $\begin{array}{l}\text { Quantity } \\
\text { (kg) }\end{array}$ & $\begin{array}{l}\text { Fat } \\
(\%)\end{array}$ & $\begin{array}{l}\text { Casein } \\
(\%)\end{array}$ & $\begin{array}{l}\mathrm{TS} \\
(\%)\end{array}$ & $\begin{array}{l}\text { Quantity } \\
(\mathrm{kg})\end{array}$ & $\begin{array}{l}\text { TS } \\
(\mathrm{kg})\end{array}$ \\
\hline A & 100 & $1.45 \pm 0.03$ & $2.45 \pm 0.09$ & $10.05 \pm 0.14$ & $91.2 \pm 0.03$ & $6.20 \pm 0.11$ \\
\hline B & 100 & $3.10 \pm 0.10$ & $5.28 \pm 0.36$ & $17.30 \pm 0.43$ & $81.20 \pm 0.03$ & $8.58 \pm 0.13$ \\
\hline $\mathrm{C}$ & 100 & $3.20 \pm 0.10$ & $5.27 \pm 0.36$ & $17.34 \pm 0.41$ & $81.12 \pm 0.03$ & $8.58 \pm 0.13$ \\
\hline
\end{tabular}

${ }^{1}$ Vat A = skim milk + whole milk (1\% starter). Vat B = whole milk + dry milk protein concentrate $(1 \%$ starter). Vat $\mathrm{C}=$ whole milk + dry milk protein concentrate $(2 \%$ starter $)$.

* Mean of duplicate analysis of four cheesemaking trials.

for proteolysis. Water-soluble fractions (WSF) of the cheeses were prepared according to the method of Kuchroo and Fox (1982), and the extract was analyzed for total $\mathrm{N}$ by the Kjeldahl method to assess primary proteolysis. Reverse-phase HPLC of the WSF of 6-mo-old cheeses was performed by the method of Farkye et al. (1995) to determine the peptide profiles. Total free amino acids (an index of secondary proteolysis) were determined by method of Folkerstma and Fox (1992).

\section{Sensory Analysis}

Sensory flavor properties of 270-d-old cheeses were analyzed by a seven-member sensory panel using 17 terms for Cheddar cheese flavor (Drake et al., 2001). The panelists had received over $80 \mathrm{~h}$ of training using the Spectrum method (Meilgaard et al., 1999), in which panelists score intensities similarly for all attributes on a 10-point universal intensity scale (Drake et al., 2001). Cheeses were prepared by slicing into $4 \times 2 \times 2$ $\mathrm{cm}$ cubes using a wire knife within $2 \mathrm{~h}$ of evaluation. Cheese cubes were dispensed into 56 -g soufflé cups with lids and tempered to $12^{\circ} \mathrm{C}$ before evaluation. Cheeses were evaluated in a balanced block design using threedigit codes under white lights. Order of presentation was randomized between panelists. Panelists had access to water and unsalted crackers throughout evalua- tion. Panelists evaluated four cheeses per session and each cheese was evaluated in duplicate.

\section{Statistical Analysis}

The data for microbial counts, composition, and proteolysis were analyzed using multivariate and univariate ANOVA models (S-Plus, Insightofud, WA). The sensory data were analyzed by ANOVA using the Statistical Analysis System (SAS) software package, Version 8.0 (SAS Institute Inc., Cary, NC).

\section{RESULTS AND DISCUSSION}

\section{Yield of Cheese}

The contents of fat, casein, and TS in the standardized WM + MPC were significantly higher than those of SM + WM blends (Table 1). Manufacture of RFC from WM + MPC resulted in reduced quantities of whey (collected at draining) compared to using $\mathrm{SM}+\mathrm{WM}$ (Table 1). The yield of RFC made from WM + SM was $7.5 \%$ compared with $\sim 18 \%(P<0.05)$ for cheese made from WM + MPC mixtures (Table 2). Cheese yields from $\mathrm{WM}+\mathrm{SM}$ are similar to earlier reports on lower-fat Cheddar cheese. Anderson et al. (1993) reported 7.5\% yield for RFC containing $18.5 \%$ fat. Ogden et al. (1993) reported yields of 7.3 to $7.8 \%$ for Cheddar cheese con-

Table 2. Mean* ( \pm SD) of fat and TS recoveries during reduced-fat cheese making from milk standardized with skim milk or dry milk protein concentrate (MPC) and yield of resultant cheese. ${ }^{1}$

\begin{tabular}{lllll}
\hline & $\begin{array}{l}\text { Actual yield } \\
(\%)\end{array}$ & $\begin{array}{l}45 \% \text { moisture } \\
\text { adjusted yield } \\
\text { (calculated) }\end{array}$ & Fat recovery $(\%)$ & $\begin{array}{l}\text { TS recovery } \\
(\%)\end{array}$ \\
\hline $\mathrm{A}$ & $7.40 \pm 0.56$ & $8.05 \pm 0.52$ & $91.85 \pm 2.68$ & $42.25 \pm 2.82$ \\
$\mathrm{~B}$ & $18.62 \pm 2.89$ & $19.96 \pm 1.89$ & $93.77 \pm 1.83$ & $61.21 \pm 4.66$ \\
$\mathrm{C}$ & $18.72 \pm 2.47$ & $20.15 \pm 2.11$ & $93.42 \pm 3.18$ & $61.70 \pm 4.15$ \\
$P$-value & 0.000 & 0.000 & 0.643 & 0.000 \\
\hline
\end{tabular}

\footnotetext{
${ }^{1}$ Vat $\mathrm{A}=$ whole milk + skim milk $(1 \%$ starter $)$. Vat $\mathrm{B}=$ whole milk + MPC $(1 \%$ starter $)$. Vat $\mathrm{C}=$ whole milk + dry milk protein concentrate ( $2 \%$ starter).

${ }^{2}$ After subtracting salt from TS of cheeses.

* Mean of duplicate analysis of four cheesemaking trials.
} 
Table 3. Composition* of reduced-fat Cheddar made from whole milk plus skim milk or dry milk protein concentrate (MPC). ${ }^{1}$

\begin{tabular}{llllccc}
\hline Vat & $\begin{array}{l}\text { Moisture } \\
(\%)\end{array}$ & $\begin{array}{l}\text { FDM } \\
(\%)\end{array}$ & $\begin{array}{l}\text { Protein } \\
(\%)\end{array}$ & $\begin{array}{l}\text { Salt } \\
(\%)\end{array}$ & $\begin{array}{l}\text { Lactose } \\
(\%)\end{array}$ & $\mathrm{pH}$ \\
\hline $\mathrm{A}$ & 41.33 & 30.91 & 33.5 & 1.20 & 0.54 & 5.30 \\
& $(0.83)$ & $(0.25)$ & $(0.83)$ & $(0.43)$ & $(0.81)$ & $\begin{array}{c}0.06) \\
\mathrm{B}\end{array}$ \\
& 41.91 & 27.50 & 33.8 & 1.21 & 0.29 & 5.24 \\
$\mathrm{C}$ & $(0.75)$ & $(1.47)$ & $(1.56)$ & $(0.18)$ & $(0.14)$ & $(0.06)$ \\
& 41.73 & 28.00 & 34.0 & 1.10 & 0.37 & 5.29 \\
$P$-value & $(0.95)$ & $(1.93)$ & $(0.93)$ & $(0.28)$ & $(0.20)$ & $(0.03)$ \\
\hline
\end{tabular}

${ }^{1}$ Vat $\mathrm{A}=$ whole milk + skim milk ( $1 \%$ starter $)$. Vat $\mathrm{B}=$ whole milk + MPC $(1 \%$ starter $)$. Vat $\mathrm{C}=$ whole milk + MPC (2\% starter).

*Mean of duplicate analysis of four cheesemaking trials; standard deviations are in parentheses.

taining 14 to $17 \%$ fat. The high cheese yield resulting from using WM + MPC was due to the high recovery of milk solids in cheese. The TS recovery was $\sim 25 \%$ higher $(P<0.05)$ than in cheese made from $\mathrm{SM}+\mathrm{WM}$ (i.e., 58 to $61 \%$ vs. 42 to $70 \%$ TS recovery). The actual yields obtained in this study are in agreement with those of St-Gelais et al. (1998) who reported yields of 8.53, 11.37, 13.98 and $14.9 \%$ when milk was enriched with ultrafiltered milk retentate powder to $3,4,5$ or $6 \%$ casein, respectively; and yields of $8.59,11.45,13.72$, and $16.17 \%$, when milk was enriched with diafiltered micofilterd retentate powder to $3,4,5$, or $6 \%$ casein, respectively.

Fat recoveries in cheeses were in the range 91 to 93\%. Differences between fat recoveries in control and experimental cheeses were not significant $(P>0.05)$. The higher yield per unit weight of milk in the vat containing WM + MPC suggests that the throughput in a factory can be increased by increasing TS in milk used for cheese manufacture.

\section{Composition of Cheese}

Table 3 shows mean compositions of 40 to $50 \%$ RFC made from SM + WM or WM + MPC were not significantly $(P>0.05)$ different. The percentage of fat in dry matter (FDM) and percentage of moisture were within the ranges of literature values for lower-fat Cheddar cheese (Anderson et al., 1993; Mistry and Anderson, 1993). The $\mathrm{pH}$ of the cheese ranged from 5.24 to 5.30 and did not change significantly during the entire period of ripening.

\section{Bacteriological Quality}

The 1-d-old control and experimental cheeses contained $\sim 10^{9}$ cfu starter bacteria per gram, consistent with observations for hard cheeses (Cogan and Beresford, 2002). Starter bacteria grew rapidly in cheese milk and curd during manufacture of Cheddar cheese, reaching $\sim 10^{8}$ to $10^{9} \mathrm{cfu} / \mathrm{g}$ at salting. Acidification or growth of starter bacteria is essentially complete at the addition of salt (McSweeney et al., 1995). Increasing starter inoculum to $2 \%$ did not influence initial cell densities in cheese. There are contradictory reports in the literature about the growth of starter bacteria in RFC. Ardo (1993) reported excessive growth of starter organisms in lowfat cheeses as compared with full-fat cheeses, while Laloy et al. (1996) reported that fat-free or $50 \%$ reducedfat Cheddar cheeses had fewer starter cells than fullfat cheese.

No growth of NSLAB was detected up to $60 \mathrm{~d}$ of ripening in all three treatments, but after $90 \mathrm{~d}$ of ripening, NSLAB counts in the MPC1 and MPC2 cheeses

Table 4. Growth of nonstarter lactic acid bacteria (NSLAB)* during ripening in reduced-fat Cheddar made from whole milk plus skim milk or dry milk protein concentrate (MPC). ${ }^{1}$

\begin{tabular}{|c|c|c|c|c|c|c|}
\hline \multirow[b]{2}{*}{ Vat } & \multicolumn{6}{|c|}{ Mean NSLAB counts (cfu/g) } \\
\hline & $30 \mathrm{~d}$ & $60 \mathrm{~d}$ & $90 \mathrm{~d}$ & 120 & $150 \mathrm{~d}$ & $180 \mathrm{~d}$ \\
\hline A & $-\mathrm{ve}^{* *}$ & $-\mathrm{ve}$ & $2.1 \times 10^{7}$ & $2.9 \times 10^{7}$ & $3.7 \times 10^{7}$ & $3.9 \times 10^{7}$ \\
\hline B & $-\mathrm{ve}$ & $-\mathrm{ve}$ & $1.0 \times 10^{5}$ & $1.1 \times 10^{7}$ & $7.0 \times 10^{5}$ & $1.2 \times 10^{6}$ \\
\hline $\mathrm{C}$ & $-\mathrm{ve}$ & $-\mathrm{ve}$ & $3.0 \times 10^{5}$ & $1.6 \times 10^{7}$ & $1.8 \times 10^{6}$ & $1.0 \times 10^{6}$ \\
\hline
\end{tabular}




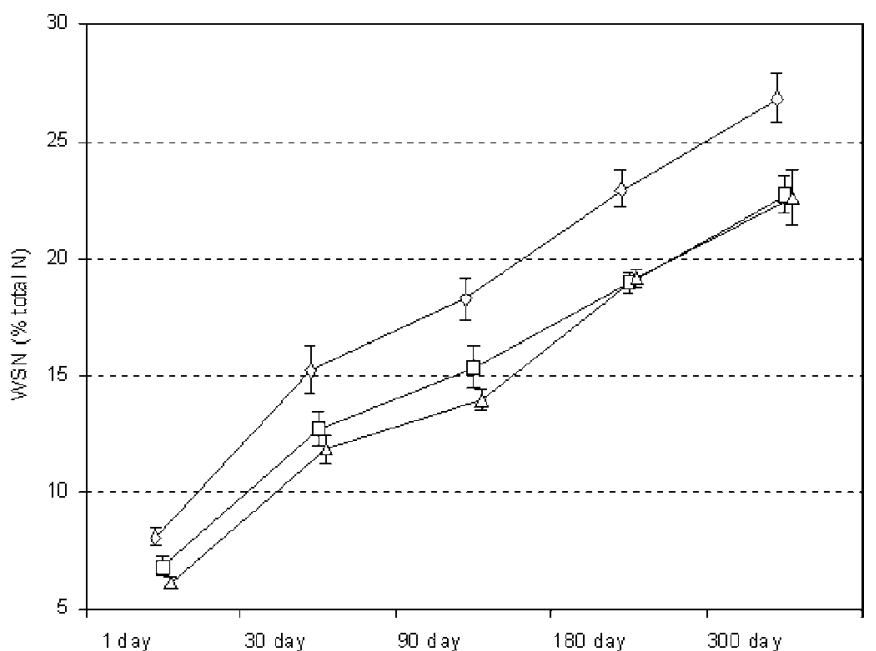

Figure 1. Water-soluble N (as \% of total N) (mean of four trials) during ripening of reduced-fat Cheddar cheese made from whole milk plus skim milk or dry milk protein concentrate (MPC). Vat A = whole milk + skim milk $(1 \%$ starter $\diamond)$. Vat $\mathrm{B}=$ whole milk + MPC $(1 \%$ starter $\square)$. Vat $\mathrm{C}=$ whole milk $+\operatorname{MPC}(2 \%$ starter $\triangle)$.

were lower by 2 log cycles than in the CC (Table 4). In pasteurized milk Cheddar cheese, NSLAB are present in low numbers $<10^{3} \mathrm{cfu} / \mathrm{g}$ at the beginning of ripening and grow to $\sim 10^{8} \mathrm{cfu} / \mathrm{g}$ within 2 to 4 mo of ripening (Cogan and Beresford, 2002). The pasteurization of milk suppresses the growth of NSLAB; it takes time for NSLAB cells to recover in hostile environment of cheese, but once they grow, the growth rate is very fast (Fox et al., 1998). In a recent study, Shakeel-ur-Rehman et al. (2003) found no growth of NSLAB in reduced-fat Cheddar up to $90 \mathrm{~d}$ of ripening. After $120 \mathrm{~d}$ of ripening, NSLAB counts were similar in all the three cheeses. However, after $180 \mathrm{~d}$, NSLAB counts were lower by 1 log cycle in MPC1 and MPC2 cheeses than in CC. This suggests that NSLAB grew slowly in the cheeses containing MPC or may have died off faster than in CC. The slow growth of NSLAB in MPC containing cheeses may be due to lower concentration of free amino acids in MPC cheeses compared to control cheese. NSLAB have been reported to utilize some amino acids and peptides as an energy source (Williams et al., 2001).

\section{Proteolysis}

The levels of WSN (as a percentage of total N) were higher in the CC than in the MPC1 and MPC2 cheeses throughout ripening (Figure 1), suggesting that the use of MPC resulted in reduced proteolysis in RFC, probably due to reduced specific activities of plasmin and/or residual chymosin in RFC manufactured from MPC + $\mathrm{WM}$ compared with that made from WM + SM. Plasmin and residual chymosin are principally responsible for
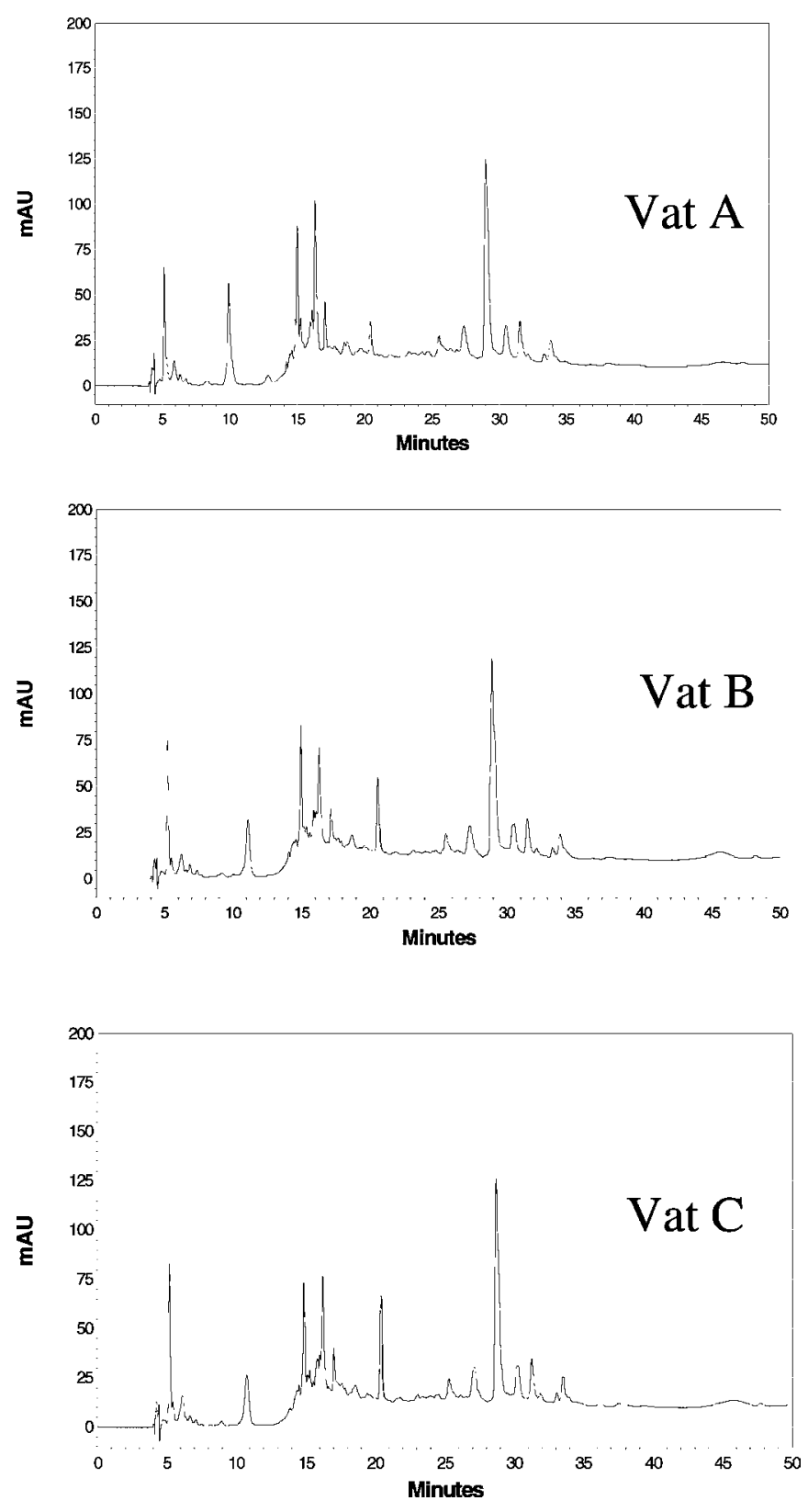

Figure 2. Reverse-phase HPLC chromatograms of water-soluble fractions of 1-d-old reduced-fat Cheddar cheese made from whole milk plus skim milk or dry milk protein concentrate (MPC). Vat A $=$ whole milk + skim milk ( $1 \%$ starter $).$ Vat $\mathrm{B}=$ whole milk + MPC $(1 \%$ starter $)$. Vat $\mathrm{C}=$ whole milk + MPC $(2 \%$ starter $)$.

the production of WS N during ripening of cheese (Shakeel-Ur-Rehman et al., 1998).

RP-HPLC of $1 \mathrm{~d}, 3$ - and 6-mo-old cheeses showed differences in the peptide profiles between control and MPC containing cheeses (Figures 2, 3, and 4). Vat A cheeses had the most peptide peaks and peak heights during ripening, suggesting greater number of peptide numbers in the water-soluble fraction compared with 

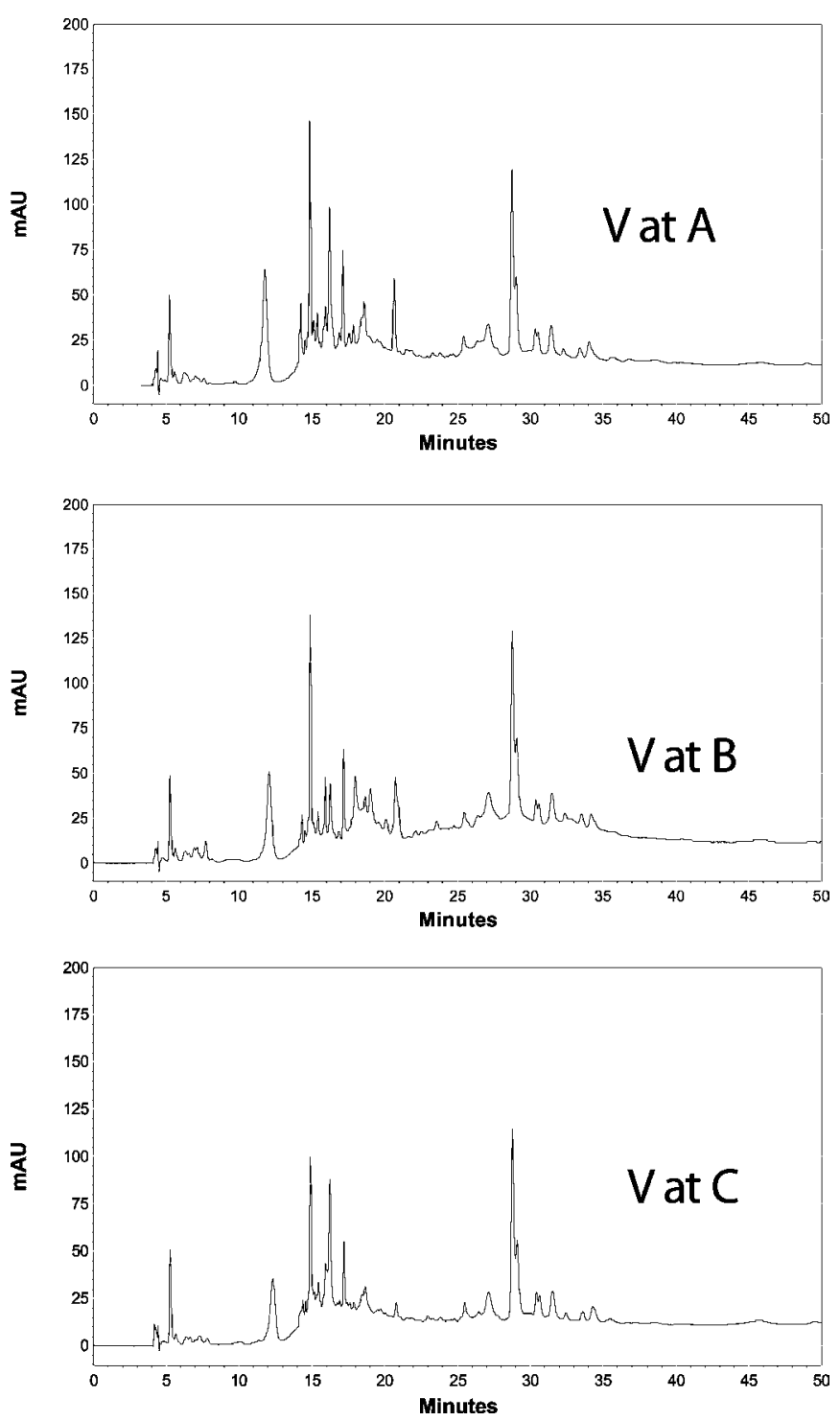

Figure 3. Reverse-phase HPLC chromatograms of water-soluble fractions of 3-mo-old reduced-fat Cheddar cheese made from whole milk plus skim milk or dry milk protein concentrate (MPC). Vat A $=$ whole milk + skim milk $(1 \%$ starter $)$. Vat $\mathrm{B}=$ whole milk + MPC $(1 \%$ starter $)$. Vat $\mathrm{C}=$ whole milk + MPC $(2 \%$ starter $)$.

MPC2 and MPC1 cheeses. Because there are differences in peptide profiles between the control and MPCcontaining cheeses before and after the outgrowth of NSLAB, the differences in the control and MPC-containing cheeses can be attributed to the sequential action of residual coagulant and starter proteinases and not to the NSLAB. Roy et al. (1997) reported that watersoluble peptides determined by RP-HPLC were similar in Cheddar cheese made from pasteurized, thermized, or microfiltered milk, although the pasteurized milk cheese had much lower number of NSLAB than the other two cheeses.
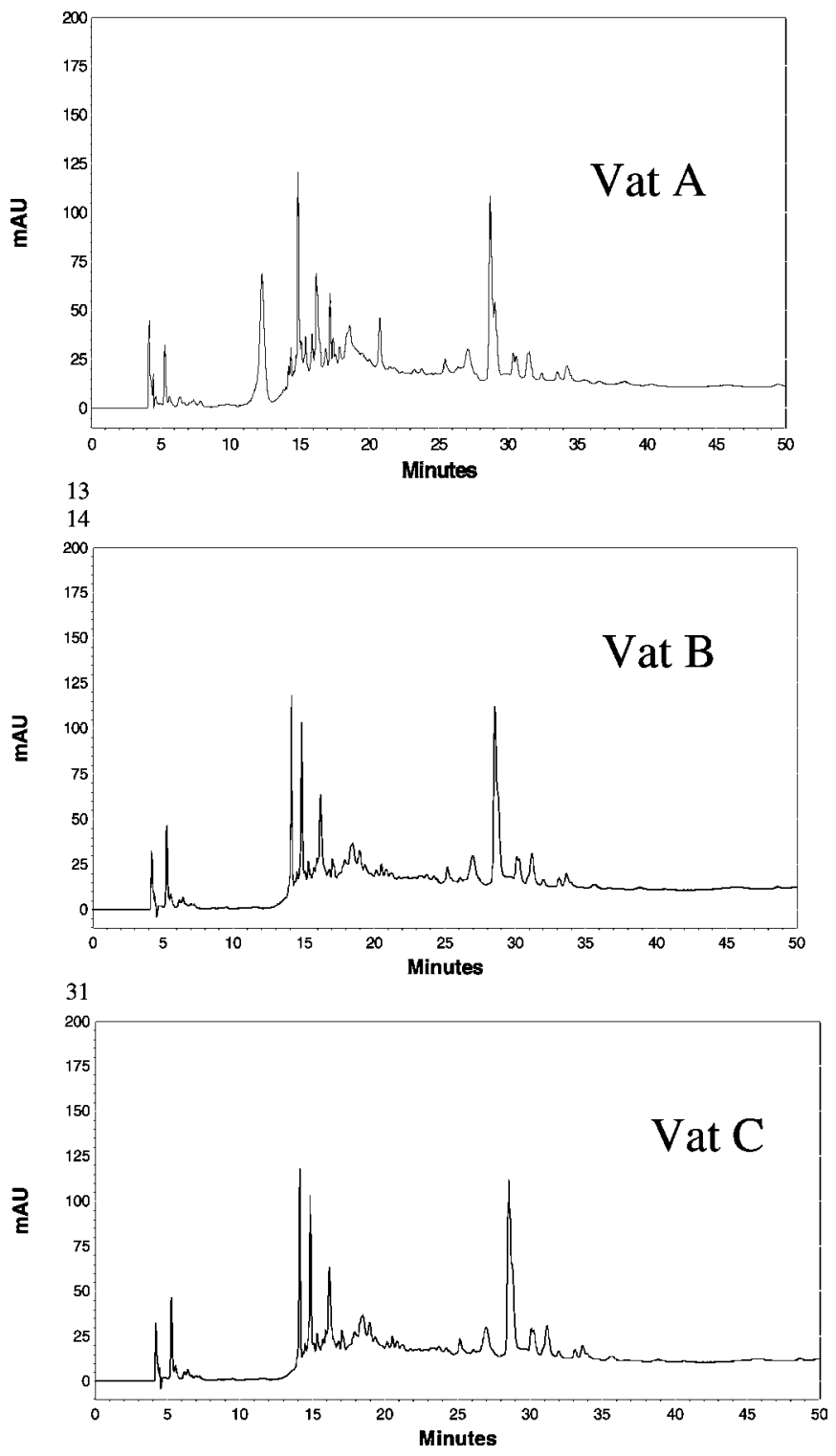

Figure 4. Reverse-phase HPLC chromatograms of water-soluble fractions of 6-mo-old reduced-fat Cheddar cheese made from whole milk plus skim milk or dry milk protein concentrate (MPC). Vat A $=$ whole milk + skim milk $(1 \%$ starter $)$. Vat $\mathrm{B}=$ whole milk + MPC $(1 \%$ starter $)$. Vat $\mathrm{C}=$ whole milk + MPC $(2 \%$ starter $)$.

The concentration of free amino acids ( $\mathrm{mg}$ of Leu/g of cheese) was markedly higher in the CC than in the MPC1 and MPC2 cheeses during the entire period of ripening (Figure 5) probably due to higher levels of peptidase activity as a result of higher starter activity and NSLAB in CC cheese. The amino acids in cheese during ripening are produced by the peptidase activity of starter or nonstarter bacteria.

\section{Sensory Evaluation}

Sensory scores for various flavor attributes are given in Table 5. Scores for "salty," "cooked," or whey flavor 


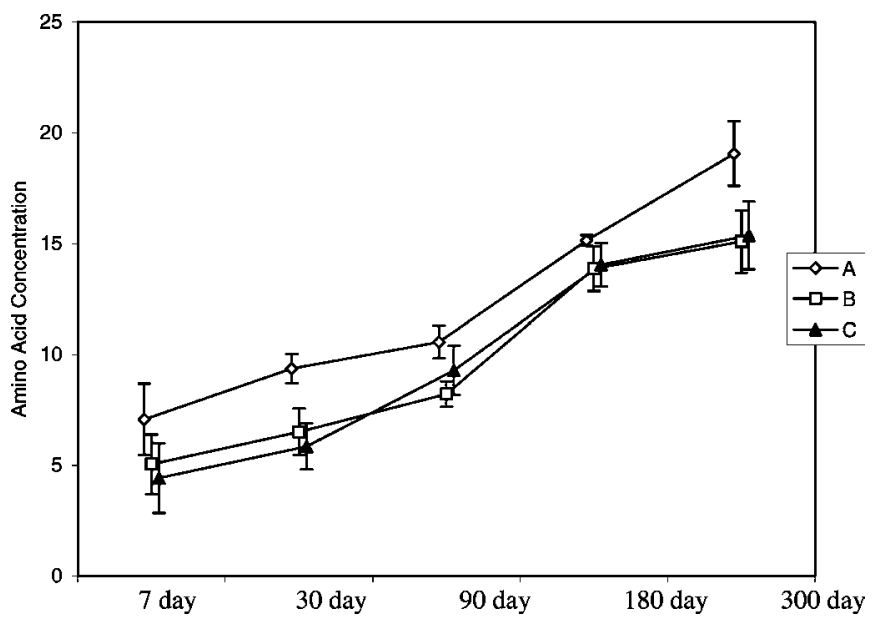

Figure 5. Development of total free amino acids (mg Leu / $\mathrm{g}$ cheese; mean of four trials) during ripening of reduced-fat Cheddar made from whole milk plus skim milk or dry milk protein concentrate (MPC). Vat A = whole milk + skim milk (1\% starter). Vat B = whole milk + MPC ( $1 \%$ starter). Vat C = whole milk + MPC ( $2 \%$ starter $).$

attributes were not significantly different among the treatments. Score for milk fat flavor was significantly lower in MPC1 cheeses than in CC. Increasing the level of starter addition from 1 to $2 \%$ in MPC2 cheeses increased milk fat flavor score probably due to liberation of small chain fatty acids as a result of higher esterase and lipase activity in MPC2 cheeses. Fruity flavor score was similar in CC and MPC1 cheeses but was significantly lower than in MPC2 cheeses, suggesting an influence of starter in fruity flavors in cheese. Sulfur and brothy flavor notes were highest in MPC2 cheeses. Sweet taste was lacking in the cheeses containing MPC.

The panelists also found that bitter flavor notes were significantly lower in cheeses containing MPC than in

Table 5. Sensory scores* of 270-d-old reduced-fat Cheddar made from whole milk plus skim milk or dry milk protein concentrate (MPC).

\begin{tabular}{llll}
\hline & \multicolumn{3}{c}{ Flavor intensity } \\
\cline { 2 - 4 } Attribute & Vat A & Vat B & Vat C \\
\hline Cooked & $2.00^{\mathrm{a}}$ & $2.00^{\mathrm{a}}$ & $2.00^{\mathrm{a}}$ \\
Whey & $3.00^{\mathrm{a}}$ & $2.50^{\mathrm{a}}$ & $3.00^{\mathrm{a}}$ \\
Salty & $2.00^{\mathrm{a}}$ & $2.5^{\mathrm{a}}$ & $2.00^{\mathrm{a}}$ \\
Fruity & $0.50^{\mathrm{b}}$ & $0.50^{\mathrm{b}}$ & $1.00^{\mathrm{a}}$ \\
Sulfur & $1.50^{\mathrm{a}}$ & $1.25^{\mathrm{a}}$ & $2.00^{\mathrm{b}}$ \\
Brothy & $3.00^{\mathrm{a}}$ & $1.00^{\mathrm{c}}$ & $2.00^{\mathrm{b}}$ \\
Milk fat & $0.75^{\mathrm{a}}$ & $0.25^{\mathrm{b}}$ & $0.50^{\mathrm{ab}}$ \\
Sweet & $0.75^{\mathrm{a}}$ & $0.00^{\mathrm{b}}$ & $0.25^{\mathrm{b}}$ \\
Bitter & $2.25^{\mathrm{a}}$ & $0.00^{\mathrm{b}}$ & $0.50^{\mathrm{b}}$ \\
Sour & $3.25^{\mathrm{b}}$ & $3.75^{\mathrm{a}}$ & $3.50^{\mathrm{ab}}$ \\
Age & $3.75^{\mathrm{a}}$ & $2.00^{\mathrm{b}}$ & $4.00^{\mathrm{a}}$ \\
\hline
\end{tabular}

${ }^{1}$ Vat $\mathrm{A}=$ whole milk + skim milk ( $1 \%$ starter $)$. Vat $\mathrm{B}=$ whole milk + MPC ( $1 \%$ starter). Vat C $=$ whole milk + MPC (2\% starter). Means in the same row followed by different letters are different $(P<0.05)$.

*Mean of duplicate analysis of four cheesemaking trials.
CC probably due to slower proteolysis, as discussed earlier (Figures 1, 2, and 3). The cheeses made with MPC and $1 \%$ starter had the lowest maturity perception compared to CC or MPC2 cheese suggesting that increasing the levels of starter to cheese milk enhances the maturity of cheese, made from high-solids milk.

\section{CONCLUSIONS}

This study demonstrated the feasibility of standardizing whole milk with MPC for reduced-fat cheesemaking. By using MPC, TS in milk increases, thereby increasing vat throughput, cheese yields, and reducing whey volume. Although increasing TS in milk with MPC resulted in slower primary and secondary proteolysis, modification of cheesemaking and use of exogenous enzymes or starter adjuncts may be needed to enhance ripening and flavor development.

\section{Acknowledgments}

The financial support of Dairy Management, Inc. and California Dairy Research Foundation is gratefully acknowledged. The help of Joan Lozano, Boris Yim, and Mihir Sainani in cheesemaking is appreciated.

\section{REFERENCES}

Anderson, D. L., V. V. Mistry, R. L. Brandsma, and K. A. Baldwin. 1993. Reduced-fat Cheddar cheese from condensed milk. 1. Manufacture, composition, and yield. J. Dairy Sci. 76:2832-2844.

Ardo, Y. 1993. Characterizing ripening in low-fat and semi-hard, round-eyed cheese made with undefined mesophilic DL-starter. Int. Dairy J. 3:343-357.

Cogan, T. M., and T. P. Beresford. 2002. Microbiology of hard cheese. Pages 515-560 in Dairy Microbiology Handbook. The microbiology of milk and milk products. R. K. Robinson, ed. Wiley and Sons, Inc., New York.

Drake, M. A., S. C. McIngvale, K. R., Cadwallader, and G. V. Civille. 2001. Development of a descriptive sensory language for Cheddar cheese. J. Food Sci. 66:1422-1427.

Dybing, S. T., S. A. Brudvig, J. A. Wiegand, and E. A. Huang. 1986. A simple method for estimating the extent of surface crystal development on colored Cheddar cheese. J. Food Prot. 49:421-422.

Farkye, N. Y., S. A. Madkor, and G. H. Atkins. 1995. Proteolytic ability of some lactic acid bacteria in a model cheese system. Int. Dairy J. 5:715-725.

Folkertsma, B., and P. F. Fox. 1992. Use of the Cd-ninhydrin reagent to assess proteolysis in cheese during ripening. J. Dairy Res. 59: $217-224$.

Fox, P. F., P. L. H. McSweeney, and C. M. Lynch. 1998. Significance of nonstarter lactic acid bacteria in Cheddar cheese. Aust. J. Dairy Technol. 53:83-89.

Kuchroo, C. N., and P. F. Fox. 1982. Soluble nitrogen in Cheddar cheese: comparision of extraction procedures. Milchwissenschaft 37:331-335.

Laloy, E., J. C. Vuillemard, M. El-Soda, and R. E. Simard. 1996. Influence of fat content of Cheddar cheese on retention and localization of starters. Int. Dairy J. 6:729-740.

Marshall, T. R., ed. 1992. Standard Methods for the Examination of Dairy Products. 15th ed. Am. Publ. Health Assoc., Inc., Washington, DC.

McSweeney, P. L. H., P. F. Fox, K. N. Jordan, T. M. Cogan, and F. D. Drinan. 1995. Role of nonstarter lactic acid bacteria in Cheddar 
cheese. In Proc 4th Cheese symposium (T. M. Cogan, P. F. Fox, and R. P. Ross, ed.). Natl. Dairy Products Res. Center, Moorpark, Cork. P32-45.

Meilgaard, M., G. V. Civille, and B. T. Carr. 1999. Descriptive analysis techniques. Ch. 10. Pages 161-170. Sensory Evaluation Techniques. 3rd Edition, CRC Press, New York.

Mistry, V. V. and D. L. Anderson. 1993. Composition and microstructure of commercial full-fat and low-fat cheeses. Food Struct. 12:259-266.

Ogden, L., H. Fisher, and B. Weimer. 1996. Will increased fat surface area help correct quality control problems caused by reduction of fat in Cheddar cheese? In Proc. 12th Bienniel Cheese Conference. Utah State Univ., Logan.

Pierre, A., F. Frauguant, Y. Le Garet, M. Piot, and J. L. Maubois. 1992 Preparation de phosphocaseinate matif par microfiltration sur membrane. Lait 72:461-474.

Price, W. V. 1953. Briefing milk calculation. The Butter, Cheese, and Milk Prod. J., 5:24-26.
Roy, D., M. Pitre, L. Blancette, L. Savoi, G. Balanger, P. Ward, and J. L. Maubois. 1997. Monitoring proteolysis and cheese juice composition during ripening of Cheddar cheese made from microfiltered milk. Lait 77:521-541.

Shakeel-Ur-Rehman, E. P. Feeney, P. L. H. McSweeney, and P. F. Fox. 1998. Inhibition of residual coagulant in cheese using pepstatin. Int. Dairy J. 12:987-992.

Shakeel-Ur-Rehman, N. Y. Farkye, and M. A. Drake. 2003. Reducedfat Cheddar cheese from a mixture of cream and liquid milk protein concentrate. Int. J. Dairy Technol. In press.

St-Gelais, D., M. Piette, and G. Belanger. 1995. Production of Cheddar cheese using milk enriched with microfiltered milk retentate: A preliminary study. Milchwissenschaft 50:614-619.

St-Gelais, D., D. Roy, and P. Audet. 1998. Manufacture and composition of low-fat Cheddar cheese milk enriched with different protein concentrate powders. Food Res. Int. 31:137-145.

Williams, A. G., J. Noble, and J. M. Banks. 2001. Catabolism of amino acids by lactic acid bacteria isolated from Cheddar cheese. Int. Dairy J. 7:157-167. 